\title{
Calcium overload in human giant cell myocarditis
}

H G Olbrich, G Herrmann, G Vandeplassche, H Michaelis, M Schneider, E Krause, G Kober

\footnotetext{
Zentrum der Inneren

Medizin, Abteilung

für Kardiologie,

Universität Frankfurt, Federal Republic of

Germany

H G Olbrich

$\mathrm{H}$ Michaelis

G Kober

Zentrum der

Pathologie,

Universität Frankfurt

G Herrmann

M Schneider

Department of Life

Sciences, Janssen

Pharmaceutica,

Beerse, Belgium

$G$ Vandeplassche

Zentrum der

Chirurgie, Abteilung

für Thorax-, Herz-

und Gefäßchirurgie,

Universität Frankfurt

E Krause

Correspondence to:

Dr Hans-Georg Olbrich,

Abteilung für Kardiologie,

Zentrum der Inneren

Medizin, Klinikum der J W

Goethe-Universität,

Theodor-Stern-Kai 7,

D-6000 Frankfurt/M 70

Federal Republic of

Germany

Accepted for publication

28 March 1990
}

\begin{abstract}
Myocardial calcium overload was observed in a patient with giant cell myocarditis. The myocardial calcium content estimated by atomic absorption spectrophotometry amounted to 120 $\mathrm{mEq} / \mathrm{kg}$ dry weight, and the von Kossa stain disclosed multiple foci with patchy calcifications of myocardial fibres. Cytochemical examination of the ultrastructural calcium localisation using the phosphate-pyroantimonate method showed considerable variation in the subcellular calcium distribution. In normal myocytes calcium precipitates were confined to the inner leaflet of the sarcolemma, T-tubules, intercalated disks, and sporadically to mitochondria. In contrast, extensive calcification of mitochondria and loss of sarcolemmal calcium was evident in necrotic myocytes. A number of grossly normal myocytes also showed an increase of calcium precipitates in slightly swollen mitochondria.
\end{abstract}

These findings suggest that myocardial calcium overload in this case started in viable myocytes and was not merely a secondary phenomenon occurring after cell death.

Myocardial calcium overload has been reported in metastatic calcification of the myocardium associated with increased serum calcium concentrations such as occur in chronic renal disease, ${ }^{1}$ osseous lesions, ${ }^{2}$ or overdoses of vitamin $\mathrm{D},{ }^{3}$ as well as dystrophic calcification without increased serum calcium concentrations as seen in ischaemic heart muscle $^{45}$ and toxic cardiomyopathies. ${ }^{6}$ These also include idiopathic calcification, as seen in the hereditary cardiomyopathy of Syrian hamsters, ${ }^{7}$ and sporadic cases in man..$^{8-10}$ In dystrophic and idiopathic calcification it still is a matter of debate whether calcium overload is a phenomenon secondary to cell death, or is a factor that itself affects viable cells and leads to irreversible cell damage. ${ }^{11}$ Most of the previous reports dealing with calcification in human hearts are confined to light microscopical and biochemical findings, which probably miss the early stages in the development of calcium overload. This report shows myocardial calcification in giant cell myocarditis. Besides light microscopical and biochemical findings it describes ultrastructural features of calcium overload in this rare myocardial disease.

\section{Case report}

A 48 year old man was admitted to hospital for the investigation of rapid progressive heart failure. He had been well until two weeks previously when he was admitted to a local hospital because of fever, dyspnoea, and weakness. Pneumonia in the left lower lobe was diagnosed. He had returned from a visit to Indonesia six weeks earlier. The patient was a frequent traveller for business to tropical regions-namely, South East Asia and South America - and therefore had had continuous annual medical check-ups since 1971. There was no history of cardiac disease except for two episodes of sinoatrial block of unknown cause in 1973 and 1974. The rest of his medical history included a tonsillectomy in 1960, a thyroidectomy in 1970, scarlet fever in 1978, and repeated episodes of colitis since 1980.

On examination, the patient had a cachectic appearance (height $1.86 \mathrm{~m}$, weight $64.2 \mathrm{~kg}$, body surface $1.9 \mathrm{~m}^{2}$ ). His pulse was 112 /minute and the blood pressure $90 / 70 \mathrm{~mm} \mathrm{Hg}$. There were signs of heart failure with an enlarged liver, distended jugular veins, and inspiratory rales at the right lung base. No peripheral oedema was present. Percussion showed that the heart was enlarged; there was a grade 2 systolic murmur and a third heart sound audible at the apex.

The complete blood count was normal except for a mild leucocytosis of $10 \cdot 1 / \mathrm{nl}$. Apart from a slight to moderate increase in aspartate aminotransferase activity (23 U/1), gammaglutamyl transpeptidase (103 U/1), alkaline phosphatase (392 U/1) and a slight decrease in serum albumin $(30 \mathrm{~g} / 1)$, the routine laboratory findings, including renal function, blood glucose, and thyroid hormones were within normal limits. Serum calcium concentration and phosphate activity were normal. Cultures from specimens of venous blood, sputum, and urine were negative. The patient was positive for hepatitis B surface antigen. Serological investigations including tests for $Q$ fever and Trypanosoma cruzi were negative except for titres of Candida albicans (1/640) and herpes zoster (IgA 0.5).

The electrocardiogram showed a first degree atrioventricular block and a complete right bundle branch block. The chest $x$ ray pictures showed pronounced cardiac enlargement (heart volume $1637 \mathrm{ml} / 1.73 \mathrm{~m}^{2}$; normal $<800 \mathrm{ml} / 1.73 \mathrm{~m}^{2}$ ), with moderate pleural effusions on both sides, and evidence of a pulmonary infiltrate in the postero-basal segment of the left lower lobe. The echocardiogram showed dilation of all heart chambers with severe global hypokinesia. An ultrasound 
scan of the abdomen showed no abnormalities other than distension of the inferior vena cava, congestion of the liver, and moderate ascites. Use of cardiac catheters disclosed a severely dilated cardiomyopathy with a left ventricular ejection fraction of $21 \%$, moderate mitral and tricuspid regurgitation, and normal coronary arteries. A biopsy specimen of the left ventricular endomyocardium disclosed evidence of an acute interstitial myocarditis with severe fibrosis.

Because of rapid progressive deterioration, a heart transplantation was required. Despite high doses of catecholamines, heart failure remained intractable. A left ventricular assist bypass was applied under general endotracheal anesthesia to maintain an adequate pressure. The following day a donor heart was available and orthotopic heart transplantation was performed, but the patient died with right ventricular failure of the donor organ, most probably due to an acute increase in pulmonary vascular resistance because of the development of shock lungs. The weight of the explanted heart was $563 \mathrm{~g}$; both ventricles were severely dilated.

At necropsy the anastomoses of the implanted heart were normal. Gross inspection of the inner organs showed acute congestion of the lungs, liver, and kidneys, and a necrotising pancreatitis.

\section{Methods}

Tissue specimens were fixed in formaldehyde and processed for routine light microscopical examination using the haematoxylin and eosin and the von Kossa stains. For immunohistochemistry, paraffin wax embedded tissue specimens from the explanted heart were examined by the avidin-biotin-peroxidase complex method. The tested primary antibodies are listed in the table. For cytochemical localisation of calcium left ventricular biopsy specimens were processed using the phosphate-pyroantimonate method. ${ }^{12}$ Duplicate unfixed portions of the left ventricle were processed for the determination of the myocardial calcium content using atomic absorption spectrophotometry.

\section{Results}

Neither giant cells nor granulomatous inflammation were identified in the extramyocardial tissues. The histological examination of the explanted heart disclosed widespread myocardial fibrosis as well as huge patchy inflammatory infiltrates comprising neutrophils, lymphocytes, some immunoblasts and plasma cells, many macrophages and numerous multinucleated giant cells. These findings were more prominent in the septum. Inflammatory cells were often adjacent to degenerated muscle cells (fig 1a). Severely degenerated myocytes were often surrounded by a garland of activated macrophages with a tendency for confluence. Giant cells sometimes contained clods of an homogenous eosin material, apparently remnants of myocytes, and their nuclei showed a striking resemblance to those of activated macrophages. Immunohistochemical characterisation of the giant cells is shown in the table. Based on these findings, acute lymphocytic myocarditis with giant cells was diagnosed. The von Kossa stain disclosed multiple foci with patchy calcifications of myocardial fibres (fig 1b). Giant cells rarely seemed to be affected by calcification. Calcified foci were scattered irregularly throughout both ventricles and the septum, predominantly sited in areas of dense inflammatory infiltrates. The calcium content of the left ventricular myocardium, as determined by atomic absorption spectrophotometry, averaged $120 \mathrm{mEq}$ of total calcium/kg dry weight.

The ultrastructural localisation of calcium with the phosphate-pyroantimonate method in the explanted heart showed a considerable variation in the subcellular calcium distribution. In most of the morphologically healthy looking myocytes calcium deposits were regularly distributed as $20 \mathrm{~nm}$ particles associated with the sarcolemma, T-tubules, and intercalated disks. Only a few calcium deposits were found in the mitochondria. In several cells, even though no gross morphological abnormalities were evident, many single calcium deposits had accumulated in slightly swollen mitochondria (fig $2 a$ ). In contrast, severely injured myocytes, showing signs of irreversible cell damage, displayed an exces-

Immunohistochemical markers of giant cells shown by avidin-biotin-peroxidase complex method

\begin{tabular}{|c|c|c|c|c|}
\hline \multirow[b]{2}{*}{ Markers/antibody } & \multirow[b]{2}{*}{ Clone/source } & \multicolumn{3}{|l|}{ Reactions } \\
\hline & & Macrophages & Giant cells & Cardiomyocytes \\
\hline $\begin{array}{l}\text { Muscle actin }{ }^{\star} \\
\text { Desmin }{ }^{\dagger} \\
\text { Granulocyte associated antigen }{ }^{\dagger} \\
\text { Leucocyte common antigen }{ }^{\dagger} \\
\text { Lysozyme }{ }^{\dagger} \\
\text { Macrophage } \dagger \\
\text { Macrophage }{ }^{\dagger} \\
\text { Mycobacteria }{ }^{\dagger} \\
\text { Myeloperoxidase }{ }^{\dagger} \\
\text { Myoglobin }{ }^{\dagger} \\
\text { Myosin }+ \\
\text { Neutrophil elastase }{ }^{\dagger} \\
\text { Alpha-l-antichymotrypsin }{ }^{\dagger} \\
\text { Alpha-1-antitrypsin }{ }^{\dagger} \\
\text { S-100 Protein }{ }^{\dagger} \\
\text { Vimentin\$ }\end{array}$ & $\begin{array}{l}\text { HHF35 } \\
\text { D33 } \\
\text { C3D-1 } \\
\text { 2B11+PD7/26 } \\
\text { rabbit } \\
\text { KP1 } \\
\text { MAC387 } \\
\text { rabbit } \\
\text { rabbit } \\
\text { rabbit } \\
\text { rabbit } \\
\text { NP57 } \\
\text { rabbit } \\
\text { rabbit } \\
\text { rabbit } \\
\text { VIM3B4 }\end{array}$ & $\begin{array}{l}(-) \\
(-) \\
(-) \\
(-) \\
(+) \\
(+++) \\
(+++) \\
(+) \\
(+++) \\
(++) \\
(+) \\
(-) \\
(+++) \\
(+) \\
(-) \\
(+++)\end{array}$ & $\begin{array}{l}(-) \\
(-) \\
(-) \\
(-) \\
(+) \\
(++) \\
(+) \\
(-) \\
(+) \\
(++) \\
(+) \\
(-) \\
(++) \\
(+) \\
(-) \\
(++)\end{array}$ & $\begin{array}{l}(+++) \\
(+++ \\
(-) \\
(-) \\
(-) \\
(-) \\
(-) \\
(-) \\
(-) \\
(+++) \\
(++) \\
(-) \\
(-) \\
(-) \\
(-) \\
(-)\end{array}$ \\
\hline
\end{tabular}

Staining intensity: $(+)=$ weakly positive, $(++)=$ moderately positive, $(+++)=$ strongly positive. Sources of reagents: ${ }^{\star}$ Enzo Biochemicals, New York; +Dakopatts, Copenhagen; ${ }_{+}^{+}$Merck, Darmstadt; §Progen, Heidelberg. 
Figure 1 Left ventricular myocardium from patient with giant cell myocarditis. (A) Area showing fibrosis, inflammatory cell infiltrate, and multinucleated giant cells (arrows). (Haematoxylin and eosin.) (B) Large area of myocardial calcification and dense inflammatory cell infiltrate. (Von Kossa stain.)

Figure 2 Localisation of calcium in the left ventricular myocardium from patient with giant cell myocarditis.

(A) Calcium deposits are bound to the sarcolemma and T-tubules (long arrows). Mitochondria are slightly swollen and contain a considerable amount of calcium deposits (short arrow) but very few osmiophilic matrix granules (arrowhead). (B) Extensive calcium accumulation in swollen mitochondria of a necrotic myocardial cell.
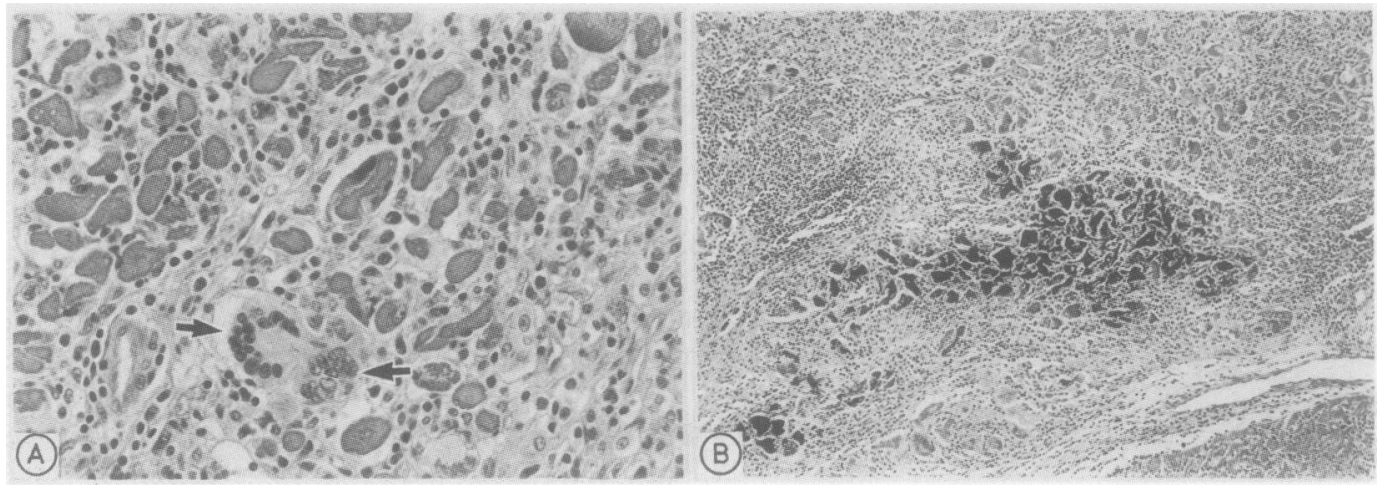

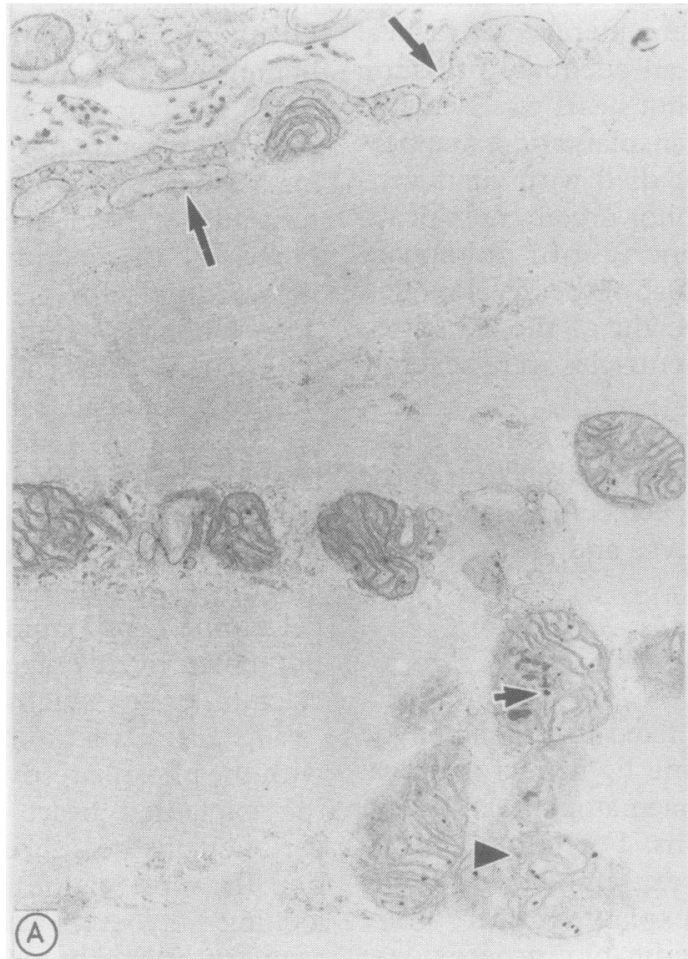

sive accumulation of clustered calcium deposits in the mitochondria; the sarcolemma was devoid of precipitate (fig $2 \mathrm{~b}$ ).

\section{Discussion}

The term giant cell myocarditis covers a variety of rare and still poorly understood diseases. In contrast to systemic diseases being associated with the occurrence of giant cells in the myocardium, such as tuberculosis and sarcoidosis, giant cell myocarditis is confined to the myocardium. ${ }^{1314}$ The diagnosis in the reported case was based on the failure to find evidence of inflammatory or granulomatous changes with giant cells in extramyocardial tissues. The aetiology and pathogenesis of giant cell myocarditis are still unknown. Viral infections and abnormal immunological phenomena have been regarded as possible causes for the disease. ${ }^{15}$ Neither isolation of nor serological evidence for an infectious organism except for a positive titre for Candida could be obtained in the present case. There was no evidence for Candida infection in the myocardium itself, but it cannot be ruled out that an abnormal immune response secondary to Candida infection led to the fatal disease.

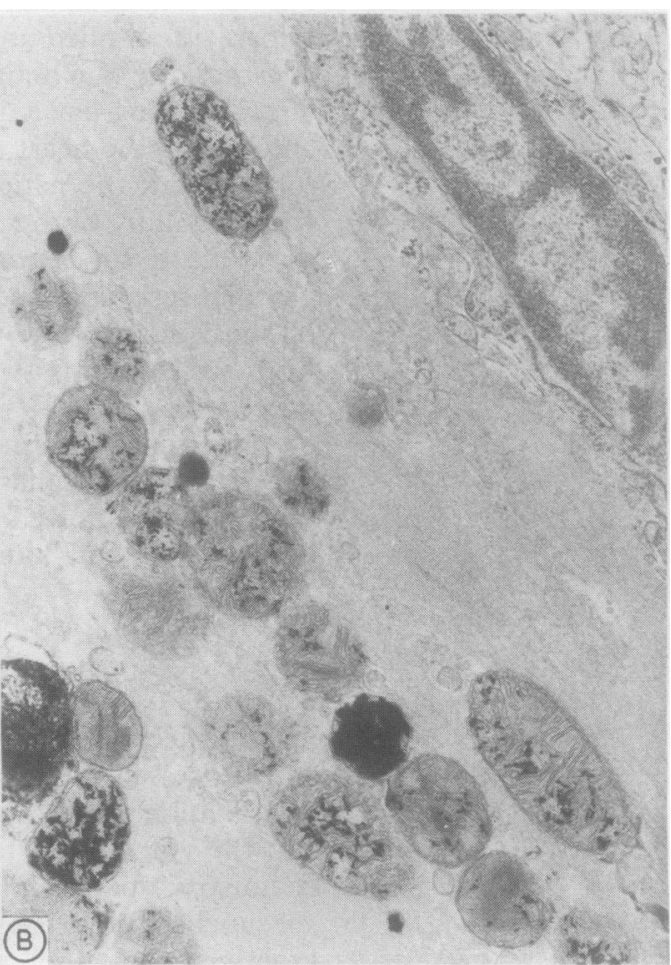

The nature of the giant cells in giant cell myocarditis has been controversial and is still a matter of conjecture. They are considered to be rather a heterogeneous group of cells of both a macrophage and a myogenic origin. ${ }^{14}{ }^{16-20}$ The giant cells observed in the present case were morphologically quite uniform. The histological and immunocytochemical findings, including the positive stain for KP1, a recently described monoclonal antibody for macrophages, ${ }^{21}$ suggest that these cells merely originated from macrophages. This agrees with the recent immunohistochemical investigations on giant cells carried out by Theaker et al. ${ }^{22}$

A pronounced myocardial calcification was associated with giant cell myocarditis. Compared with normal data from animals as well as from humans, ${ }^{1023}$ the total myocardial calcium content in our patient was very high. As the serum calcium concentration was normal this myocardial calcium overload might be regarded as either idiopathic or dystrophic.

In the present case the ultrastructural calcium distribution was localised cytochemically in a human myocarditis. In morphologically healthy myocytes the phosphate-pyroantimonate method disclosed a calcium distribution which corresponds to that found in other 
mammalian species. ${ }^{24-27}$ According to these reports, the calcium precipitate is predominantly confined to the inner leaflet of the sarcolemma, the $\mathrm{T}$-tubule system, and the intercalated disks. In contrast, only a little precipitate is found in the mitochondria. The sarcolemmal bound calcium precipitate represents an exchangeable calcium pool, ${ }^{28} 29$ which might be related to the calcium binding of acidic phospholipids of the membrane bilayer. ${ }^{3031}$ In myolytic cells we observed an extensive intramitochondrial calcium accumulation up to complete mitochondrial calcification; the plasma membrane was devoid of calcium precipitate. This might be regarded as the expression of a final intracellular calcium overload in irreversibly injured myocytes. ${ }^{32}$ Between normal myocardium and those severely damaged calcified myocytes we found a considerable variation in the mitochondrial calcium deposition. The observation of an intramitochondrial calcium accumulation in cells which otherwise morphologically appeared to be quite normal, might reflect an early stage of change in calcium homeostasis, resulting in an increased intracellular calcium concentration. We think it worth while to emphasise this as it suggests that myocardial calcium overload in this case started in viable myocytes and was not merely a secondary phenomenon occurring in irreversibly damaged cells.

The reason for myocardial calcium overload in the present case is unknown. Possible pathogenetic mechanisms include an increase in endogenous catecholamines in the final stage of heart failure combined with the contribution from intensive treatment with exogenous catecholamines. ${ }^{334}$ The focal occurrence of calcified myocytes showed by the von Kossa stain could also reflect microvascular disturbances, probably due to the inflammatory process or to increased cardiac sympathetic activity. ${ }^{35}$ Furthermore, a direct toxic action-for example, an immune response leading to membrane damage with consecutive intracellular calcium gain-cannot be excluded. ${ }^{36}$

We gratefully acknowledge the excellent technical assistance of $\mathrm{Mr}$ Fred Thone. This work was supported by the Deutsche Forschungsgemeinschaft $(0159 / 2-1)$.

1 Terman DS, Alfrey AC, Hammond WS, Donndekinger T, Ogden DA, Holmes JH. Cardiac calcification in uremia: a clinical, biochemical and pathological study. $A m \mathrm{~J} \mathrm{Med}$ 1971;50:744-55.

2 Wells HG, Holley SW. Metastatic calcification in osteitis deformans (Paget's disease of bone). Arch Pathol Lab Med 1942;34:435-42.

3 Bauer JM, Freyberg RH. Vitamin D intoxication with metastatic calcification. $J A M A$ 1946;130:1208-15.

4 Brean HP, Marks JH, Sossman MC, et al. Massive calcification in infarcted myocardium. Radiology 1950;43:33-9.

5 Borgers M, Liu GS, Xhonneux R, Thoné F, Van Overloop $P$. Changes in ultrastructure and $\mathrm{Ca}^{2+}$ distribution in the solated working rabbit heart after ischemia. A time related study. Am J Pathol 1987;126:92-102.

6 Azuma J, Sperelakis N, Hasegawa $\mathrm{H}$, et al. Adriamycin cardiotoxicity: possible pathogenetic mechanisms. $J \mathbf{M o}$ Cell Cardiol 1981;13:381-97.

7 Jasmin G, Eu HY. Cardiomyopathy of hamster dystrophy. Ann NY Acad Sci 1979;317:46-58.
8 Duke $M$. Massive calcification of the myocardium of unknown origin. Arch Pathol Lab Med 1957;64:34-8.

9 Herrmann G, Haupt GJ, Birhead NC. Rapid myocardial calcification after cardiac surgery. JAMA 1963;186: 260-1.

10 Pardo-Mindán FJ, Herreros J, Marigil MA, Arcas R, Diez J. Myocardial calcification following heart transplantation. $J$ Heart Transplant 1986;5:332-5.

11 Cheung JY, Bonventre JV, Malis CD, Leaf A. Calcium and ischemic injury. $N$ Engl J Med 1986;314:1670-6.

12 Borgers M, Thoné F, Xhonneux BJM, De Clerck FFP. Localization of calcium in red blood cells. J Histochem Cytochem 1983;31:1109-16.

13 Whitehead R. Isolated myocarditis. Br Heart $J$ 1965;27: 220-30.

14 Davies MJ, Pomerance A, Teare RD. Idiopathic giant cell myocarditis-a distinctive clinico-pathological entity. $\mathrm{Br}$ Heart $J$ 1975;37:192-5.

15 Laufer A, Davies AM. Experimental granulomatous myocarditis: genesis and immunologic aspects. Ann NY Acad Sci 1969;156:91-104.

16 Pyun KS, Kim YH, Katzenstein RE, Kikkawa Y. Giant cell myocarditis. Light and electron microscopic study. Arch Pathol Lab Med 1970;90:181-8.

17 Sekiguchi M, Numao Y, Imai M, Furuie T, Mikami R. Clinical and histopathological profile of sarcoidosis of the heart and acute idiopathic myocarditis. Concepts through a study employing endomyocardial biopsy. I. Sarcoidosis. $J p n$ Circ J 1980;44:249-63.

18 Tubbs RR, Sheibani K, Hawk WA. Giant cell myocarditis Arch Pathol Lab Med 1980;104:245-6.

19 McAllister Jr HA, Ferrans VJ. Granulomas of the heart and major blood vessels. In: Joachim HL, ed. Pathology of granulomas. New York: Raven Press, 1983:75-123.

20 Tanaka M, Ichinohasama R, Kawahara $Y$, et al. Acute idiopathic interstitial myocarditis: case report with special reference to morphological characteristics of giant cells. $J$ reference to morphological chat

21 Pulford KAF, Rigny EM, Micklem KJ, et al. KP1: a new monoclonal antibody that detects a monocyte/macrophage associated antigen in routinely processed tissue sections. $J$ Clin Pathol 1989;42:414-21.

22 Theaker JM, Gatter KC, Brown DC, Heryet A, Davies J. An investigation into the nature of giant cells in cardiac and skeletal muscle. Hum Pathol 1988;19:974-9.

23 Lossnitzer K, Steinhardt B, Grewe N, Stauch M. Characteristic electrolyte changes in the hereditary myopathy and cardiomyopathy of the Syrian golden hamster. Basic Res Cardiol 1975;70:508-20.

24 Borgers M, Thoné F, Verheyen A, Ter Keurs HEDJ. Localization of calcium in skeletal and cardiac muscle. Histochem $J$ 1984;16:295-309.

25 Flameng W, Xhonneux R, Van Belle $\mathrm{H}$, et al. Cardioprotective effects of Mioflazine during $1 \mathrm{~h}$ normothermic globa ischemia in the canine heart. Cardiovasc Res 1984;18 528-37.

26 Liu GS, Borgers M, Xhonneux R, et al. Evaluation of protective effect of Lidoflazine and Mioflazine in cardiac ischemia. Drug Devel Res 1986;8:407-16.

27 Olbrich HG, Borgers M, Thoné $F$, et al. Ultrastructural localization of calcium in the myocardium of cardiomyopathic Syrian hamsters. J Mol Cell Cardiol 1988;20:753-62.

28 Borgers $M$. The role of the sarcolemma-glycocalyx complex in myocardial cell function. In: De Bakey ME, Gotto AM, eds. Factors influencing the course of myocardial ischemia. Amsterdam: Elsevier Science Publishers, 1983:55-65.

29 Wheeler-Clark ES, Tormey McD. Electronic probe X-ray microanalysis of sarcolemma and junctional sarcoplasmic reticulum in rabbit papillary muscles: low sodiuminduced calcium alterations. Circ Res 1986;60:246-50.

30 Lüllmann H, Peters T. Plasmalemmal calcium in cardiac excitation-contraction coupling. Clin Exp Pharmacol Physiol 1977;4:49-57.

31 Philipson KD, Bers DH, Nishimoto AY. The role of phospholipids in the $\mathrm{Ca}^{+}$-binding of isolated sarcolemma. phospholipids in the Ca $\mathrm{a}^{+}$-binding of isol
$J$ Mol Cell Cardiol 1980;12:1159-73.

32 Farber JL, Chien KR, Mittnacht S. The pathogenesis of irreversible cell injury in ischemia. Am J Pathol irreversible cell

33 Ferrans VJ, Hibbs RG, Walsh JJ, Burch GE. Histochemical and electron microscopical studies on the cardiac necrosis produced by sympathomimetic agents. Ann NY Acad Sci 1969;156:309-32.

34 Fleckenstein A, Janke J, Döring $H J$, Leder O. Die intrazelluläre Uberladung mit Kalzium als entscheidender Kausalfaktor bei der Entstehung nicht-coronarogener Myokardnekrosen. Verh Dtsch Ges Kreislaufforsch 1971;37:345-53.

35 Sole MJ, Factor SM. Hamster cardiomyopathy. A genetically transmitted sympathetic dystrophy? In: Beamish RE, Panagia V, Dhalla NS, eds. Pathogenesis of stressinduced heart disease. Boston: Martinus Nijhoff, 1984:34-43.

36 Schultheiss HP, Kühl U, Janda I, Melzner B, Ulrich G, Morad M. Antibody-mediated enhancement of calcium permeability in cardiac myocytes. J Exp Med 1988;168:2105-19. 